\title{
Ra mắt cuốn sách Bằng chứng cuộc sống - Suy nghĩ về phát triển bền vững Việt Nam
}

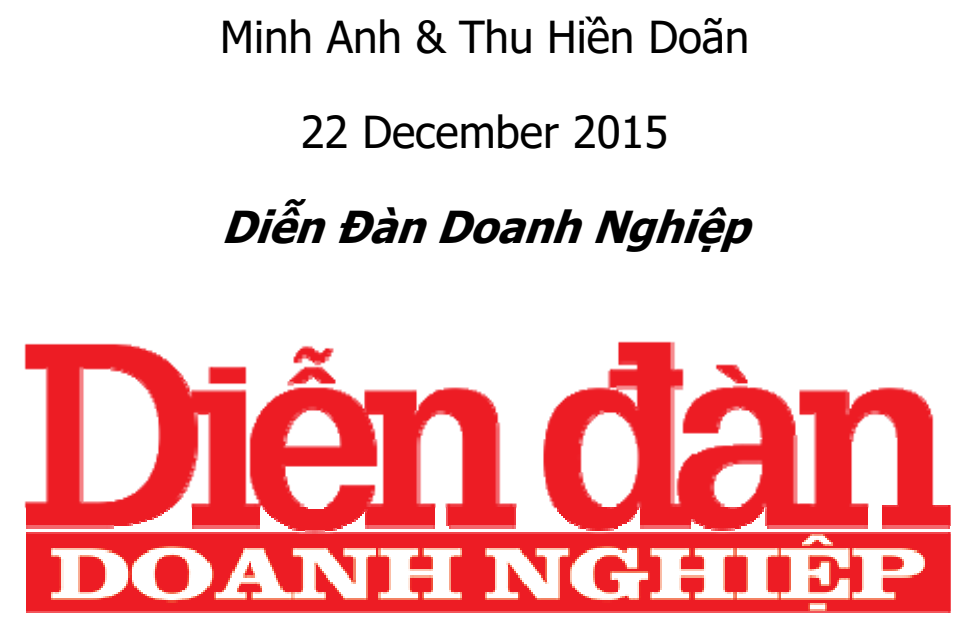

https://enternews.vn/ra-mat-cuon-sach-bang-chung-cuoc-song-suy-nghive-phat-trien-ben-vung-viet-nam-94405.html 


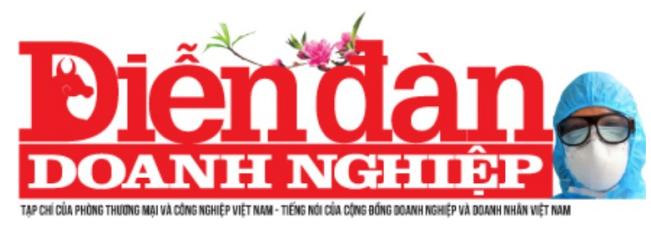

Ra mắt cuốn sách I"Bằng chứng cuộc sống - Suy nghĩ về phát triển bền vững Việt $\mathrm{Naml"}$

(DĐDN) - Nhà xuất bản Chính trị quốc gia - Sự thật vừa xuất bản cuốn sách Bằng chứng cuộc sống - Suy nghĩ về phát triển bền vững Việt Nam của đồng tác giả Bạch Ngọc Chiến và Vương Quân Hoàng.

(DĐDN) - Nhà xuất bản Chính trị quốc gia - Sự thật vừa xuất bản cuốn sách Bằng chứng cuộc sống Suy nghĩ về phát triển bền vững Việt $\mathrm{Nam}$ của đồng tác giả Bạch Ngọc Chiến và Vương Quân Hoàng.

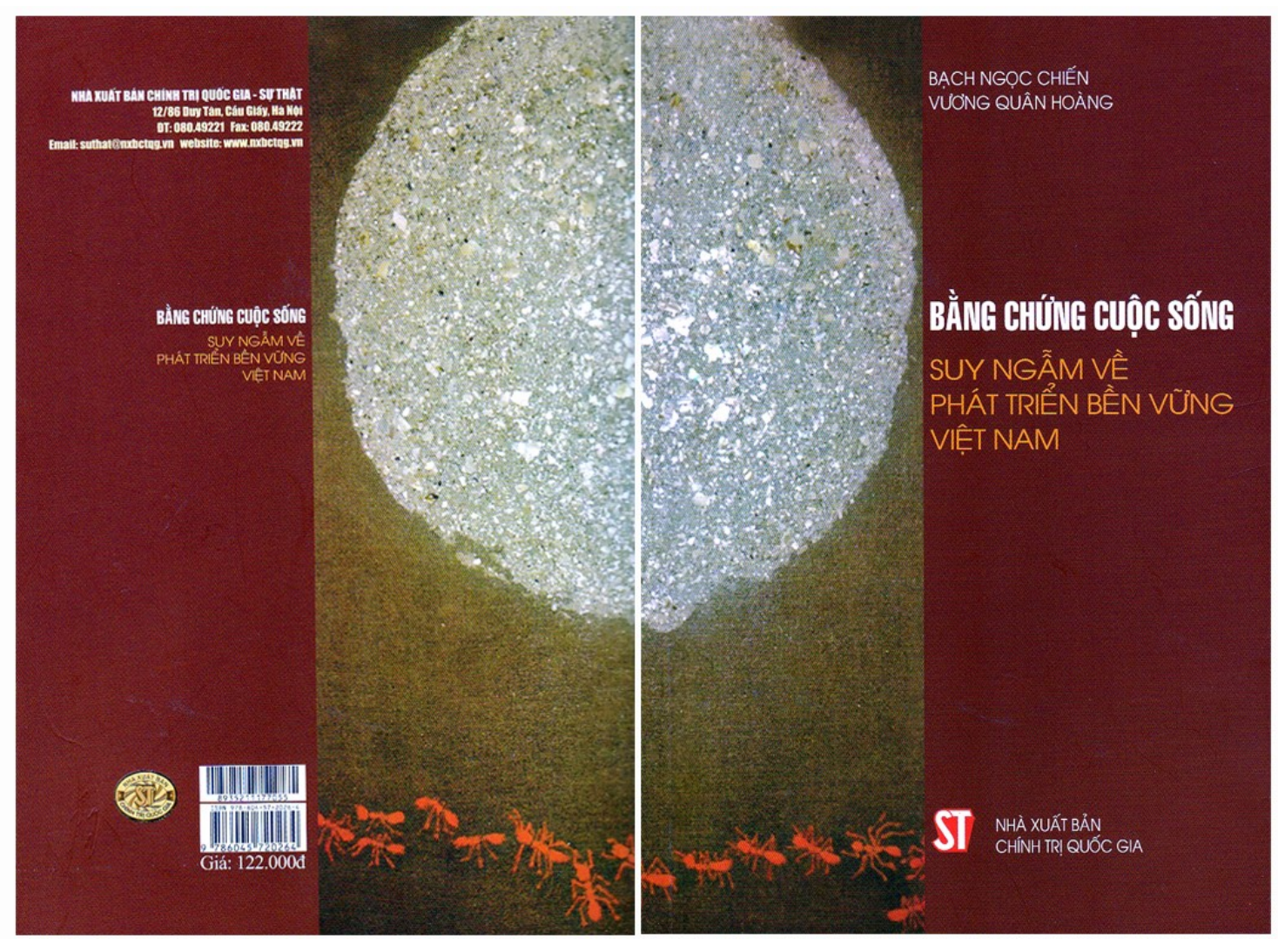

Đồng tác giả của cuốn sách chia sẻ: Dự án "Bằng chứng cuộc sống - Suy nghĩ về phát triển 
bền vững Việt Nam" được thai nghén từ 3 năm trước, khi hai tác giả có dịp hợp tác với nhau trong một công việc dài hơi khác. Lúc ấy mỗi người ở một phía của ranh giới trách nhiệm: hỏi và đáp. Dù dự án đó kết thúc cuối năm 2013 nhưng quá trình "hỏi - đáp" này không dừng lại mà trở thành cuộc tranh luận bất tận. Quy mô mở rộng ra, sự nhất trí và dị biệt cũng tăng lên. Và đến khi vấn đề trở nên phức tạp hơn, đòi hỏi sự tập trung và suy ngẫm sâu sắc cũng như tinh thần trách nhiệm cao hơn thì dự án "Bằng chứng cuộc sống - Suy nghĩ về phát triển bền vững Việt Nam" ra đời. Đó là vào khoảng giữa năm 2014.

Với kết cấu gồm 5 chương chính: (Chương 1: Mạch nguồn; Chương 2: Con người, xã hội và nhà nước; Chương 3: Sức vóc kinh tế; Chương 4: Trí lực quốc dân; Chương 5: Tiến hóa) cùng tư duy và phương pháp tiếp cận khoa học, các tác giả đã dẫn dắt bạn đọc đi từ các quan sát về lịch sử hình thành dân tộc, sự phát triển và hoàn thiện của con người, xã hội, nhà nước trong tiến trình lịch sử đến sự phát triển kinh tế của đất nước ta. Mục tiêu cuối cùng mà các tác giả muốn đề cập tới là phương pháp và năng lực tổ chức, thiết kế và thực thi những kế hoạch phát triển phù hợp trong điều kiện hạn chế về nguồn lực và đối mặt với những thay đổi của cực diện trong nước và quốc tế.

Cuốn sách thể hiện quá tình nghiên cứu công phu, nghiêm túc. Nội dung cuốn sách cũng đã giúp làm sáng tỏ nhiều câu hỏi, gợi mở cách nhìn nhận về tương lai phát triển của đất nước.

Cuốn sách là một trong những câu trả lời hữu ích trong bối cảnh gần 100 triệu người dân Việt Nam và kiều bào đứng trước những câu hỏi về sự phát triển trong tương lai, khả năng đáp ứng với thách thức thời đại, vị trí của cá nhân - tập thể trong viễn cảnh kinh tế - xã hội... ngày càng nhiều người có thể tiếp cận được với khối lượng thông tin, phân tích phong phú, đa dạng, nhưng phải đối mặt với thách thức về phương pháp tiếp cận. Đặc biệt khi phạm vi phân tích đó nằm ở tầm quốc gia , trong mối quan hệ quốc tế vừa gia tăng nhanh chóng lại vừa đan xen, thách thức trở nên rất phức tạp. Ngay cả khi tìm được những phân tích có thể tương đối thuyết phục và đáng tin thì những gợn nghi vấn cũng không dễ gì xóa được.

Điểm nhấn của cuốn sách là phép tương tự với sự sống thiên nhiên- xã hội và sự vận hành của hệ văn hóa - xã hội như DNA định nghĩa đặc tính di truyền xã hội trong tương lai.

\section{Minh Anh}

Thu Hiền Doãn 


\section{TÀI LIẸU THAM KHẢO}

1. Bạch Ngọc Chiến, Vương Quân Hoàng. (2015). Bằng chứng cuộc sống: Suy ngẫm về phát triển bền vững Việt Nam. NXB Chính trị Quốc gia, Hà Nội.

2. Phạm Minh Chính, Vương Quân Hoàng. (2009). Kinh tế Việt Nam: Thăng trầm và đột phá. NXB Chính trị Quốc gia, Hà Nội. 